\title{
1 Applied and Environmental Microbiology
}

4 Inhibition of select actinobacteria by the organophosphate pesticide chlorpyrifos

6 Nathan D. McDonald ${ }^{1}$, Courtney E. Love ${ }^{1,2}$, Rushyannah Killens-Cade ${ }^{3}$, Jason Werth ${ }^{4}$, 7 Matthew Gebert ${ }^{6}$, Carolyn F. Weber ${ }^{4}$, Christopher Nealon ${ }^{5}$, Charles Sweet ${ }^{5}$, Noah 8 Fierer $^{6}$, and Henry S. Gibbons ${ }^{1 \neq}$

${ }^{1}$ United States Army Combat Capabilities Development Command-Chemical Biological

11 Center, Aberdeen Proving Ground, Maryland, USA

122 JRAD, Inc., Stafford Virginia

${ }^{3}$ Division of CBRN Countermeasures, Biomedical Advanced Research and Development Authority, Washington, DC, United States

$15{ }^{4}$ Department of Biological Sciences, Idaho State University, Pocatello, ID

${ }^{\ddagger}$ Corresponding author, henry.s.gibbons.civ@mail.mil 
21

\section{ABSTRACT}

pesticides as well as chemical nerve agents. Decades of research have demonstrated numerous links between these chemicals and their direct and indirect effects on humans and other organisms. The inhibitory effects of organophosphate pesticides (OPPs) on metazoan physiology, are well-characterized; however, the effects of organophosphorus compounds on soil microbes - essential contributors to key agricultural processes - are poorly understood. Chlorpyrifos (CPF) is an OPP that is used globally for crop protection. Studies of CPF application to soils have shown transient effects on soil microbial communities with conflicting data. Here, we directly test the effect of CPF on a panel of 196 actinobacteria strains, examining the effects of CPF on their growth and in vitro phenotypes on solid media. Strains were grown and replica-plated onto media containing CPF or a vehicle control and grown at $28^{\circ} \mathrm{C}$. CPF dramatically inhibited the growth of most strains and/or altered colony morphologies, with 13 strains completely inhibited by CPF. In disk diffusion assays with CPF, its degradation product 3,5,6-trichloropyridinol (TCP), malathion, parathion, monocrotophos and mevinphos, only CPF exhibited direct antimicrobial activity suggesting that the observed effects were due to CPF itself.

\section{IMPORTANCE}

Chlorpyrifos is a globally used pesticide with documented neurological effects on nontarget organisms in the environment. Finding that chlorpyrifos can inhibit the growth of 
42 some soil microbes in vitro may have implications for the composition, stability, and

43 health of the soil microbiome. Due to the importance of soil microbes to numerous

44 biogeochemical processes in agricultural systems, additional investigations into the non-

45 target effects of CPF on soil microbes are clearly needed.

\section{INTRODUCTION}

The global pesticide era began in the mid- $20^{\text {th }}$ century, ushering in marked improvements in the agricultural industry and beyond (1). The production of crops benefited from dramatically increased yields through the second half of the $20^{\text {th }}$ century (2). While many factors contributed to the surge in crop production, there is no doubt that the expanded use of herbicides and pesticides played an integral role. Beyond increased yields and reduced crop losses, pesticide use has also led to better control of vector-borne diseases (1). Despite these benefits, the use of pesticides does not come without associated risk. A growing body of evidence has demonstrated various off-target effects of many pesticides on humans, other animals, and the environment (3-5). in commercial agriculture worldwide. The OPPs function by forming a covalent OPPenzyme adduct that leads to irreversible inhibition of the enzyme acetylcholinesterase (AChE), which terminates synaptic transmission by degrading the neurotransmitter acetylcholine (6). When OPPs bind to AChE, the enzyme hydrolyzes the OPP, leaving a phosphoryl group in the active site, irreversibly inhibiting AChE. Organophosphate pesticides are a major cause of intentional poisoning worldwide with early exposure 
symptoms including fatigue, salivation, and convulsions, ultimately leading to death by asphyxiation in acute cases (7). The toxic effects of OPPs on humans and other animals has been well documented, and the Environmental Protection Agency banned the residential use of many OPPs in 2001 (8-14). Despite this ban, many of these pesticides (Fig. 1) are still widely used in agriculture (15).

One of the most widely used and studied OPPs is chlorpyrifos (CPF) (Fig.1). Since its first introduction to the market in 1965, CPF has become the insecticide of choice for more than 50 types of crops in over 100 countries worldwide and is applied to 8.5 million crop acres per year $(16,17)$. Off-target exposure to CPF is associated with toxicity towards aquatic organisms (18-22), pollinators (23-26) and birds (18, 27-30). Additionally, several studies have shown a link between CPF exposure and adverse side effects on humans and other mammals (12, 31-38).

In contrast to the well-documented effects on human and animal health, the effects of OPPs on microbial populations following exposure to OPPs has received little study. Soil bacteria and fungi play an essential role in many agricultural processes, serving as key controls on soil nutrient cycling and other processes (39-42). It is well known that soil microbiomes contribute to overall soil fertility and crop yield (43-46). While there is limited and conflicting data on the effects of OPPs on microbes, several studies have investigated the possibility of utilizing bacteria as tools for CPF bioremediation (47-57). In fact, enzymes that degrade CPF, most notably organophosphate hydrolases, are present in various bacterial species (58-62). This bacterial degradation is believed to be one of the primary mechanisms by which CPF is removed from the environment (reviewed in (48)). While it is clear that there is interplay 
87 between soil microbes and CPF, the specific effects of this OPP and OPPs as a whole on soil microbes have not been well-studied. A few previous studies have demonstrated that exposure to CPF results in shifts in bacterial populations $(48,56,63$, 64); however, whether these shifts are due to inhibition of select microbes, enhanced growth, or a combination of both is less clear. It is also unclear if there are taxonspecific differences in bacterial responses to CPF.

Actinobacteria are one of the more abundant groups of bacteria found in soils across the globe (65). Actinobacteria are Gram-positive, high $\mathrm{G}+\mathrm{C}$ content bacteria, many of which display characteristics of fungi such as production of differentiated multicellular structures (i.e., substrate mycelia, and aerial hyphae). While actinobacteria are predominantly found in soils, they can also be abundant in air and aquatic environments (66). Actinobacteria play significant roles in a variety of economic and environmental processes of importance. Actinomycetes affect crop production by fixing nitrogen, recycling organic matter, promoting plant growth, and in some cases, through plant pathogenesis $(65,66)$. $(65,66)$. Additionally, actinomycetes produce metabolites including antimicrobials, antifungals, and enzymes involved in bioremediation of numerous substances including OPPs $(47,57)$. actinobacteria. Utilizing a panel of recently isolated actinobacteria, we demonstrate that the growth of many of the strains is delayed or completely inhibited following exposure 107 to CPF. In addition, we noted several altered phenotypes including colony morphology 108 and pigmentation. Using a modified Kirby-Bauer disk-diffusion assay, we demonstrate that inhibiton effects are specific to CPF, as its main degradation product 3,5,6- 
110 trichloropyridinol (TCP) and several other OPPs had no effect on bacterial growth. We

111 next tested a panel of defined species across the actinobacteria obtained from the

112 Agricultural Research Service (ARS) Northern Regional Research Laboratory (NRRL)

113 culture collection for susceptibility to CPF. Across this panel we found that grwoth

114 inhibition is specific to CPF, but not all species are equally affected and strains within

115 the same species can exhibit resistant and sensitive phenotypes. This study provides

116 evidence that CPF is able to inhibit the growth of specific actinobacterial taxa commonly

117 found in soil.

118 Results

119

120

121

122

123

124

125

126

127

128

129

130

131

132

\section{Chlorpyrifos exposure results in phenotypic changes in Actinomycetes}

To determine whether CPF affects the growth of bacteria representative of taxa commonly found in soil ecosystems, we began with an array screen of 196 diverse strains within the family Actinomycetales grown in the presence or absence of CPF. The actinomycete panel represents strains/species which were isolated via air sampling across three geographical regions in the United States, including two sites in Maryland, one near Boulder Colorado., and one near Pocatello, Idaho (67). A final concentration of $10 \mu \mathrm{M}$ was selected because it would represent the effect of solubilizing the recommended field application of the pesticide in $2.54 \mathrm{~cm}$ of rainfall. Following the incubation, 144 of the 196 strains grew on the control plate which will serve as the reference (Fig. 2). Comparing the reference plates to the CPF plates we observed phenotypic changes in the presence of the OPP. Most notably, the majority of these observed phenotypes were related to growth inhibition (Fig. 2). Specifically, 44 strains (30.5\%) exhibited delayed growth compared to the DMSO control. Delayed growth was 
scored by microbial growth on the CPF plates which was visibly reduced compared to the same strain on the reference plate. The library screen revealed that 33/144 (22.9\%) strains were completely inhibited with no visible growth in the presence of CPF after the 3 day incubation compared to same strain on the control plate where growth was observed. Together these data show that, of the 144 strains that grew on the control media, a total of 77 (53\%) were either partially or completely inhibited in growth by 10 $\mu \mathrm{M}$ CPF (Fig. 2) In addition to the effects on growth, CPF affected colony shape and coloration, which were likely due to delayed formation of aerial hyphae and/or sporulation (9/144; 6\%) (Fig. 2). Taken together, these results indicate that, for individual species or strains, CPF at agriculturally relevant concentrations can have profound effects, with growth inhibition frequently observed. Of those CPF-responsive strains for which 16S rRNA gene sequences were obtained, all were species of Streptomyces. This finding is most likely due to the composition of the panel, which was originally intended to detect cryptic antimicrobial metabolites and as such contains a high proportion of Streptomyces spp., with minor representation ( 10\%) from other actinomycete clades (Micromonospora, Lentzea, Nocardia, Nocardiopsis, and Amycolatopsis), and was repurposed for this study.

\section{Chlorpyrifos exposure results in delayed growth of specific soil microbes}

To eliminate the possibility that the inhibition we observed might be a secondary effect resulting from CPF-induced biosynthesis of cryptic secondary metabolites, a potential result of stimulation by exogenous chemical triggers $(68,69)$ or co-culture with other bacterial species (70), we next examined the effects of CPF on pure cultures of a panel of strains that were inhibited by CPF in the arrays. Utilizing select strains from the 
collection we determined the inhibitory effect of CPF by measuring colony diameter after a defined growth period. Spore preparations from four strains in the collection were plated on ISP2 agar plates containing either DMSO or $10 \mu \mathrm{M}$ CPF and incubated for 3 days at $28^{\circ} \mathrm{C}$. Following incubation, colony diameters were measured and all tested strains exhibited a significant reduction in colony diameter upon exposure to CPF (Fig.

3). Specifically, strains B-2682, ECBC9.7, and QLW15 exhibited a 59.21\%, 51.18\%, and $72.6 \%$ decrease in colony diameter respectively, compared to these strains exposed to DMSO alone. Additionally, after the 3-d incubation period, there were no visible colonies from strain USNA 39.6B when plated on the CPF containing media (Fig. 3). We sequenced the $16 \mathrm{~S}$ rRNA gene regions of the strains affected by CPF and have tentatively identified them as Streptomyces griseus B-2682, Streptomyces paulus ECBC

\section{7 and Streptomyces fulvissimus QLW15.}

\section{Actinomycete growth inhibition is specific to chlorpyrifos exposure}

Having demonstrated that CPF inhibited a subset of organisms in our actinomycete collection, we next wanted to determine if these effects were observed with other OPPs. To test the effects of multiple OPPs, we conducted zone of inhibition experiments with the following compounds: (1) DMSO control, (2) CPF, (3) 3,5,6trichloropyridinol, (4) malathion, (5) parathion, (6) monocrotophos, and (7) mevinphos (phosdrin). While not an organophosphorous compound, 3,5,6-trichloropyridinol (TCP) is one of the main degradation products of CPF upon hydrolysis, and previous reports have suggested that TCP has antimicrobial properties $(49,50,71,72)$. We speculated that the antimicrobial activities of TCP may explain the growth inhibition phenotypes we observed with CPF upon hydrolysis in the media. Whatman paper disks $6 \mathrm{~mm}$ in 
179 diameter were soaked with $10 \mu \mathrm{L}$ of a $10 \mathrm{mM}$ stock solution for each compound and added to ISP2 plates with the indicated strain spread to form a lawn. The plates were monitored for growth and inhibition zones daily. We utilized Mycobacterium smegmatis as a well characterized actinobacterium control. We found that for each of the four strains tested, with the exception of M. smegmatis which was unaffected, CPF specifically inhibited growth whereas there was no observable effect from the alternative OPPs or TCP (Fig. 4). Additionally, similar to the observation on colony diameter, the effect of CPF was variable between strains tested, with some being more sensitive than others as indicated by the formation of larger zones of clearance or inhibition (Fig. 4). Across the strains tested here, at the given concentration, we did not observe any antimicrobial effects from TCP, suggesting that the inhibition associated with CPF is specific and not a result of degradation to TCP (Fig. 4).

We next wanted to determine whether the delayed growth in the presence of

192 CPF was a phenotype observable across diverse species of bacteria. We conducted disk-diffusion assays with the same panel of OPPs tested against the actinomycetes with representative bacteria: Escherichia coli, Bacillus subtilis, Bacillus thuringiensis, Staphylococcus epidermidis and Burkholderia thailandensis. Following incubation, none 196 of the compounds at the given concentration exhibited any deleterious effects to growth 197 against the strains tested here (Fig. 5). Taken together these data demonstrate that, at 198 the tested concentrations of OPPs, only select actinomycetes are specifically 199 susceptible to CPF exposure. 
Since many strains in our own collection have not been well characterized, and

Streptomyces, we sought to better understand the taxonomic breadth of inhibition by

testing a selection of soil associated actinomyces species/strains obtained from the

206 The collection was chosen to represent phylogenetically diverse actinomycetes found in

207 various soil environments. The collection was evaluated for CPF-induced sensitivity via

208 the zone of inhibition test comparing $10 \mu \mathrm{M}$ CPF or DMSO control. Similar to the

209 observations described above, we found that CPF had variable inhibitory effects

210 towards some isolates in our NRRL panel (Table 1). In general, the phenotypes could

211 be classified as either a large zone of inhibition (ZOI), a small ZOI, growth up to but not

212 on the CPF disk, or completely unaffected by CPF (Table 1). In total, 8 of the 19 strains

213 tested (42\%) exhibited measurable ZOI upon CPF exposure (Table 1). The most

214 dramatic example of CPF sensitivity was observed in Micromonospora chokoriensis for

215 which we measured a ZOI of $40.5 \mathrm{~mm}$ (Table 1). This particular strain of

216 Micromonospora chokoriensis was isolated from soy bean roots in Illinois, USA. This

217 isolation source is particularly relevant as soybeans are one of the main target crops for

218 CPF application (16). In screening our panel of representative actinomycetes, there are

219 differences in CPF sensitivities between highly related bacterium, such as

220 Kibdelosporangium aridum subspecies aridum which exhibited a ZOI of $12.2 \mathrm{~mm}$ and

221 Kibdelosporangium aridum subspecies largum which was unaffected by CPF exposure

222 (Table 1). Collectively, these results align with those from our internal collection in that 
223 the inhibition of growth upon CPF exposure only effects select actinomyces and differences in sensitivity exist between related strains/species.

225 Discussion

With this work, we set out to characterize the impact of OPPs on soil microbes.

227 This class of insecticides has been highly scrutinized because of its deleterious effects on non-target organisms such wildlife and humans, particularly agricultural workers.

229 Despite these concerns associated with OPPs, millions of tons are used annually in agriculture systems worldwide, ultimately making their way into the food supply (73). While the risks to humans are documented, much less is understood regarding the potential for OPPs to interact with the soil microbiota. As an essential component of agricultural ecosystems, alterations in soil microbe populations may result in deleterious

234 downstream outcomes. Therefore, we set out to specifically determine how OPPs affect 235 the growth of soil actinomycetes.

We found that when specific actinomycetes are exposed to chlorpyrifos at

237 agriculturally relevant concentrations, there is significant growth inhibition and, in some 238 cases, strains were completely unable to grow. While the in vitro concentration we 239 selected $(10 \mu \mathrm{M})$ assumed full solubilization of the compound, the solubility of CPF in 240 water is $1.4 \mathrm{mg} \mathrm{L}^{-1}$ or $4.0 \mu \mathrm{M}(74)$. Therefore the actual exposure to CPF in situ may 241 vary, the compound can adsorb to soil particles due to its high soil partition coefficient 242 (75). Given that streptomyces species in particular display hydrophobic structures that 243 protrude outside of aqueous environments and potentially in direct proximity to soil 244 particles $(65,76-80)$, it is possible that the mode of interaction with the pesticide in 
245 these experiments may not represent in situ exposure routes. We speculate that the hydrophobic nature of the aerial hyphae, which are expressed within and between soil particles $(81,82)$ may allow relatively insoluble CPF and other pesticides to partition to the surface structures of actinomycete species, and potentially increase access to cellsurface targets. unknown. OPPs and similar compounds can inhibit a variety of non-target enzymes,

252 particularly serine proteases and esterases. In separate activity-based protein profiling studies, analogs of CPF and the nerve agent VX were shown to bind and form adducts with several molecular targets in addition to cholinesterases (83-85), including enzymes involved in the TCA cycle. Furthermore, the organophosphate reagent diisopropylfluorophosphonate is commonly used as a non-specific serine protease 257 inhibitor. The isolation of resistant or hypersensitive mutants and identification of bacterial CPF-binding enzymes should illuminate the mechanism by which CPF blocks

259 growth or the mechanisms by which isolates resist inhibitory action of CPF.

261 into account potential effects of CPF on the complex microbial communities in which

262 these strains exist in soils. The complexity of the soil microbiome may offer protection

263 from the toxic effects of OPPs through mechanisms such as biodegradation or by

264 providing protected niches within single- or multispecies biofilms. Previous

265 investigations examining the impact of pesticides on microbes have primarily focused 
267 several conflicting reports regarding how microbial populations are affected(51, 56, 63, 268 86-88).

In our experiments, the growth inhibition was specific to certain strains of bacteria while others remained unaffected by CPF. A recent study analyzed the effects of CPF

271 and malathion on microbes and enzyme activity in soil collected from Punjab, India. This

272 study found that in soil containing CPF and malathion at concentrations ranging from

$273 \quad 10-250$ ppm there was no significant loss in total microbial populations or actinomycetes

274 specifically (63). Comparatively, in our studies, at lower CPF concentrations (3.5 ppm),

275 we observed species/strain specific inhibition of actinomycetes. These findings would

276 suggest that at coarser levels of taxonomic resolution, there may not be observable

277 changes in population, while changes at the species level - such as selective inhibition

278 by CPF - would be missed.

The data presented have demonstrated that there are members of the

280 actinomycete family which are CPF resistant and others which are inhibited by CPF.

281 The CPF induced inhibition of select microbes decreases competition for the resistant

282 population, allowing for niche expansion. Supporting the potential for oopossible niche expansion following CPF exposure, there are several examples of actinomycete strains that are capable of degrading CPF and utilizing the pesticide as a sole carbon source

$285(47,57)$. In the environment, it is possible that CPF is inhibiting select actinomycetes

286 while others are resistant or even growing on CPF thereby shifting community-level 287 dynamics within the group. we did not observe any effects from chlorpyrifos' main degradation product or several 
other OPPs tested. Previous studies have demonstrated that malathion at $50 \mathrm{ppm}$ decreased actinomycete populations in soil by $37 \%$ in one week following application (89). The absence of growth inhibition with malathion observed in this study could be related to the low concentration used here (only $3.5 \mathrm{ppm}$ ). It is possible that higher concentrations of malathion could lead to growth inhibition.

In the environment, CPF readily hydrolyzes to the primary degradation product 3,5,6-trichloropyridinol (TCP), which has its own associated risks and health concerns $(37,90,91)$. Numerous biodegradation studies, focused on utilizing microbes to remediate CPF found that the accumulation of TCP hindered microbial growth $(49,50$, $71,72)$. We speculated that CPF-mediated inhibition of actinomycetes was due to hydrolysis to TCP in the media. We found that, at the concentrations tested, TCP did not inhibit any of the strains which were sensitive to CPF demonstrating that the inhibition was specific to CPF. A previous study demonstrated that the chlorpyrifos oxon, an intermediate degradation metabolite, was $\sim 26$ times more inhibitory than CPF towards soil microbes (88). It is possible that the growth phenotypes observed in this study are a result of CPF oxon interactions, which should be explored in further detail.

There is likely no "magic bullet" pesticide which exhibits no off-target effects while providing the benefits needed to support agricultural needs worldwide. This study sheds light on how the prevalent organophosphate pesticide CPF can selectively exhibit antimicrobial effects on actinomycete subpopulations. Finding that some actinomycetes are unaffected by CPF suggests that there are genetic elements and/or associated phenotypes present within these strains that confer resistance to CPF. One possible explanation for CPF resistance is the presence of hydrolases which can degrade CPF in 
313 the environment prior to the molecule accessing the cytoplasm. A second possibility is

314 that the low solubility of CPF prevents it from crossing the inner membrane in resistant

315 strains whereas sensitive strains may specifically or nonspecifically transport CPF into

316 the cell. It is not clear why CPF is the active compound against the sensitive strains

317 here and not TCP which has previously been reported to exhibit antimicrobial activity.

318 Previous studies have shown that at sub acetylcholinesterase inhibitory concentrations,

319 CPF can inhibit non-target hydrolases in mammalian tissues $(85,92,93)$. It is possible

320 that CPF is inhibiting essential hydrolases in the sensitive actinomycetes resulting in

321 growth defects. Further investigations should be directed at illuminating the mechanism

322 of action for CPF growth inhibition in these organisms. While total actinomycete

323 population counts may not necessarily be changed upon CPF exposure, this study

324 highlights that CPF exposures most likely alters the taxonomic composition of soil

325 actinomycete communities.

\section{$326 \quad$ Materials and Methods}

327 Collection of the actinobacterial strain library. The actinomycete library was

328 assembled from organisms isolated from air samples. The details of actinobacteria

329 isolation and detailed analysis of the collection composition will be published elsewhere

330 (R. Killens-Cade et al., in preparation). Briefly, strains were collected and isolated onto

331 Humic Acid Vitamin Agar or Kings B Medium using a SASS-180 single-stage impact

332 sampler (Bioscience International, Rockville, MD, USA) or an MAS-EC0100 (EMD

333 Millipore, St. Louis MO) using published methods (94). Colonies exhibiting 
sporulation) were streaked to homogeneity, sporulated on solid media, and stocked using standard methods (95).

Strains and culture conditions. The actinobacteria were routinely cultured from frozen spore preparations via inoculation into Difco International Streptomyces Project (ISP) medium 2 (ISP2) (Becton, Dickinson and Company, Spark, MD) and incubated at $28^{\circ} \mathrm{C}$. The actinobacteria listed in table 1 were obtained from ARS NRRL culture collection (https://nrrl.ncaur.usda.gov/cgi-bin/usda/index.html) and were selected to include a broad representation across the actinobacteria. When pesticides were included in the growth medium, they were diluted from a $10 \mathrm{mM}$ stock solution in DMSO directly to the growth medium after sterilization.

Replica plating soil microbe library. Frozen spore preparations were used to inoculate $1 \mathrm{ml}$ volumes of International Streptomyces Project-2 (ISP2) medium in deep 96-well plates (Enzyscreen BV, Heemstede, The Netherlands) and incubated at $28^{\circ} \mathrm{C}$ at 300rpm for $96 \mathrm{~h}$ after which most cultures became turbid (67). The outgrowth was then used to replicate the libraries on International Streptomyces Project- 4 (ISP4) agar containing either $10 \mu \mathrm{M} \mathrm{CPF}$ or DMSO control and incubated for 3 days at $28^{\circ} \mathrm{C}$.

Disk-diffusion studies using organophosphate pesticides. Single colony picks from ISP2 plates were added to $1 \mathrm{~mL} 0.1 \%$ PBS-Tween80 for spore-forming organisms. Non-actinobacteria bacteria inoculations were prepared with a single colony into $5 \mathrm{~mL}$ of LB broth and shaken at $37^{\circ} \mathrm{C}$ for about 5 hours, until turbid. Actinobacteria were spread onto ISP2 agar, non-actinobacteria were spread onto Mueller Hinton agar, at $400 \mu \mathrm{L}$ for each plate. Once absorbed, 6-mm diameter Whatman paper disks soaked in $10 \mu \mathrm{L}$ of 
$35710 \mathrm{mM}$ pesticide in dimethyl sulfoxide (DMSO) or in a solvent-only control were placed

358 on the agar surface and transferred to the incubator for growth. Actinobacteria were

359 grown at $28^{\circ} \mathrm{C}$, non-actinobacteria at $37^{\circ} \mathrm{C}$, and monitored for growth daily. Plates were

360 removed from the incubator once lawns were observed.

\section{Acknowledgements}

363 Funding was provided by the Defense Threat Reduction Agency. This research was performed while N.D.M held an NRC Research Associateship award at CCDC-CBC.

We thank Soumia Bekka and Andrew Marinich for assistance with environmental sampling at CCDC-CBC.

Table 1: Evaluation of NRRL representative actinomycetes exposed to CPF

\begin{tabular}{|c|c|c|c|c|c|}
\hline $\begin{array}{l}\text { NRR } \\
\text { L }\end{array}$ & Strain name & Order & $\begin{array}{l}\text { Isolation } \\
\text { Source }\end{array}$ & ZOI & $\begin{array}{l}\text { Growt } \\
\text { h on } \\
\text { disk }\end{array}$ \\
\hline $\begin{array}{l}\text { B- } \\
1612 \\
1\end{array}$ & Actinomadura citrea & $\begin{array}{l}\text { Streptosporangia } \\
\text { les }\end{array}$ & Soil & $N / A$ & $\mathrm{~N}$ \\
\hline $\begin{array}{l}\text { B- } \\
1232 \\
7\end{array}$ & $\begin{array}{l}\text { Actinomadura luteofluores } \\
\text { cens }\end{array}$ & $\begin{array}{l}\text { Streptosporangia } \\
\text { les }\end{array}$ & Soil & $\mathrm{N} / \mathrm{A}$ & $\mathrm{N}$ \\
\hline $\begin{array}{l}\text { WC- } \\
3860\end{array}$ & Amycolatopsis lurida & Pseudonocardia & $\begin{array}{l}\text { Soil, Colorado } \\
\text { Springs, } \\
\text { Colorado, USA }\end{array}$ & $\mathrm{N} / \mathrm{A}$ & $\mathrm{N}$ \\
\hline $\begin{array}{l}\text { B- } \\
2415 \\
0\end{array}$ & Amycolatopsis rubida & $\begin{array}{l}\text { Pseudonocardial } \\
\text { es }\end{array}$ & $\begin{array}{l}\text { Conifer forest } \\
\text { soil, Guangxi } \\
\text { Province, China }\end{array}$ & $\mathrm{N} / \mathrm{A}$ & $\mathrm{N}$ \\
\hline $\begin{array}{l}\text { B- } \\
2483\end{array}$ & Amycolatopsis viridis & $\begin{array}{l}\text { Pseudonocardial } \\
\text { es }\end{array}$ & $\begin{array}{l}\text { Composite soil, } \\
\text { Australia }\end{array}$ & $\mathrm{N} / \mathrm{A}$ & $\mathrm{N}$ \\
\hline
\end{tabular}




\begin{tabular}{|c|c|c|c|c|c|}
\hline 7 & & & & & \\
\hline $\begin{array}{l}\text { B- } \\
1643 \\
6\end{array}$ & $\begin{array}{l}\text { Kibdelosporangium } \\
\text { aridum } \\
\text { subspecies aridum }\end{array}$ & $\begin{array}{l}\text { Pseudonocardial } \\
\text { es }\end{array}$ & Soil & $\begin{array}{l}12 . \\
2 \\
\mathrm{~mm}\end{array}$ & $\mathrm{~N}$ \\
\hline $\begin{array}{l}\text { B- } \\
2446 \\
2\end{array}$ & $\begin{array}{l}\text { Kibdelosporangium } \\
\text { aridum } \\
\text { subspecies largum }\end{array}$ & $\begin{array}{l}\text { Pseudonocardial } \\
\text { es }\end{array}$ & Desert soil, USA & $\mathrm{N} / \mathrm{A}$ & $\mathrm{N}$ \\
\hline $\begin{array}{l}\text { B- } \\
2428 \\
4\end{array}$ & Kitasatospora kifuensis & Streptomycetales & Soil, Japan & $\begin{array}{l}15 . \\
4 \\
\mathrm{~mm}\end{array}$ & $\mathrm{~N}$ \\
\hline $\begin{array}{l}\text { B- } \\
2475 \\
0\end{array}$ & $\begin{array}{l}\text { Micromonospora } \\
\text { chokoriensis }\end{array}$ & $\begin{array}{l}\text { Micromonosporal } \\
\text { es }\end{array}$ & $\begin{array}{l}\text { Soy bean roots, } \\
\text { Calhoun County, } \\
\text { Illinois, USA }\end{array}$ & $\begin{array}{l}40 . \\
5 \\
\mathrm{~mm}\end{array}$ & $\mathrm{~N}$ \\
\hline $\begin{array}{l}\text { B- } \\
2346\end{array}$ & Micromonospora species & $\begin{array}{l}\text { Micromonosporal } \\
\text { es }\end{array}$ & Unknown & $\begin{array}{l}13 . \\
1 \\
\mathrm{~mm}\end{array}$ & $\mathrm{~N}$ \\
\hline $\begin{array}{l}\text { B- } \\
2414 \\
5\end{array}$ & Nocardiopsis composta & $\begin{array}{l}\text { Streptosporangia } \\
\text { les }\end{array}$ & $\begin{array}{l}\text { Air near } \\
\text { composting } \\
\text { facility, Kassel, } \\
\text { Germany }\end{array}$ & $\mathrm{N} / \mathrm{A}$ & $\mathrm{N}$ \\
\hline $\begin{array}{l}\text { B- } \\
1612 \\
7\end{array}$ & $\begin{array}{l}\text { Nonomuraea } \\
\text { roseoviolacea } \\
\text { subspecies roseoviolacea }\end{array}$ & $\begin{array}{l}\text { Streptosporangia } \\
\text { les }\end{array}$ & $\begin{array}{l}\text { Dry-heated soil, } \\
\text { Yamanashi } \\
\text { Pref., Japan }\end{array}$ & $\mathrm{N} / \mathrm{A}$ & $\mathrm{N}$ \\
\hline $\begin{array}{l}\text { B- } \\
2407 \\
2\end{array}$ & $\begin{array}{l}\text { Saccharopolyspora } \\
\text { erythraea }\end{array}$ & $\begin{array}{l}\text { Pseudonocardial } \\
\text { es }\end{array}$ & & $\begin{array}{l}12 . \\
1 \\
\mathrm{~mm}\end{array}$ & $\mathrm{~N}$ \\
\hline $\begin{array}{l}\text { B- } \\
1617 \\
3\end{array}$ & Saccharopolyspora taberi & $\begin{array}{l}\text { Pseudonocardial } \\
\text { es }\end{array}$ & $\begin{array}{l}\text { Soil, Texas, } \\
\text { USA }\end{array}$ & $\begin{array}{l}11 . \\
1 \\
\mathrm{~mm}\end{array}$ & $\mathrm{~N}$ \\
\hline $\begin{array}{l}\text { B- } \\
2682\end{array}$ & $\begin{array}{l}\text { Streptomyces griseus } \\
\text { subspecies griseus }\end{array}$ & Streptomycetales & Soil, USA & $\begin{array}{l}12 . \\
5 \\
\mathrm{~mm}\end{array}$ & $\mathrm{~N}$ \\
\hline $\begin{array}{l}\text { B- } \\
1693 \\
2\end{array}$ & $\begin{array}{l}\text { Streptomyces } \\
\text { spinoverrucosus }\end{array}$ & Streptomycetales & Air & $\begin{array}{l}14 . \\
8 \\
\mathrm{~mm}\end{array}$ & $\mathrm{~N}$ \\
\hline $\begin{array}{l}\text { B- } \\
2639\end{array}$ & $\begin{array}{l}\text { Streptosporangium } \\
\text { amethystogenes }\end{array}$ & $\begin{array}{l}\text { Streptosporangia } \\
\text { les }\end{array}$ & $\begin{array}{l}\text { Soil, Yamanashi } \\
\text { Pref., Japan }\end{array}$ & $\mathrm{N} / \mathrm{A}$ & ND \\
\hline $\begin{array}{l}\text { B- } \\
1643 \\
7\end{array}$ & Streptosporangium fragile & $\begin{array}{l}\text { Streptosporangia } \\
\text { les }\end{array}$ & Soil, Sri Lanka & $\mathrm{N} / \mathrm{A}$ & $\mathrm{N}$ \\
\hline $\begin{array}{l}\text { B- } \\
2633\end{array}$ & $\begin{array}{l}\text { Streptosporangium } \\
\text { vulgare }\end{array}$ & Streptosporangia & $\begin{array}{l}\text { Paddy field soil, } \\
\text { Anjo, Aichi Pref., }\end{array}$ & $\mathrm{N} / \mathrm{A}$ & Y \\
\hline
\end{tabular}




\section{Figure Legends}

Figure 1: Representative organophosphate pesticides

\section{3} treatments.

\section{Figure 2: Screening the effects of chlorpyrifos exposure against a library of}

actinomycetes. A library of 196 actinomycetes were replica plated on media containing DMSO (Top) or $10 \mu \mathrm{M}$ CPF (Bottom). Of the 196 strains plated 144 representative grew on the DMSO control plates which served as the reference. The strains grown on CPF were compared to the counterpart on DMSO media.

Figure 3: Effect of chlorpyrifos on colony size. Four Streptomyces strains were each inoculated onto an ISP2 agar plate with $10 \mu \mathrm{M}$ CPF or DMSO and incubated for 3 days at $26^{\circ} \mathrm{C}$. The diameter of a sampling of colonies was measured, represented (Top). The mean diameters for each strain tested were determined (bottom). Error bars represent SD. ${ }^{* \star *} p<0.001$ based on unpaired t-test between mean diameters from $+/-$ CPF

\section{Figure 4: Determining the inhibitory effects of organophosphate pesticides on} actinomycetes. Four Streptomyces strains and Mycobacterium smegmatis were each inoculated onto an ISP2 agar plate with discs dosed with $10 \mu \mathrm{L}$ of $10 \mu \mathrm{M}$ of (1) DMSO; (2) CPF; (3) TCP; (4) Malathion; (5) Parathion; (6) Monocrotophos; (7) Mevinphos and incubated allowing lawns to form. Following incubation zones of inhibition (ZOIs) were measured for each of the compounds tested. 
Figure 5: Determining the inhibitory effects of organophosphate pesticides on

391

392

393

394

395

396

397

398

399

400

401

402

403

404

405

406

407

408

409

410

411

412

413

414

415

416

417

418

419

420

421 non-actinomycetes. Four representative bacteria: Bacillus thuringiensis serovar

kurstaki, Burkholderia thailandensis, Escherichia coli and Staphylococcus epidermidis

were each inoculated on appropriate media with discs dosed with $10 \mu \mathrm{L}$ of $10 \mu \mathrm{M}$ of (1)

DMSO; (2) CPF; (3) TCP; (4) Malathion; (5) Parathion; (6) Monocrotophos; (7)

Mevinphos and incubated allowing lawns to form. Following incubation zones of

inhibition (ZOIs) were measured for each of the compounds tested.

\section{References}

1. Aktar MW, Sengupta D, Chowdhury A. 2009. Impact of pesticides use in agriculture: their benefits and hazards. Interdiscip Toxicol 2:1-12.

2. Warren GF. 1998. Spectacular Increases in Crop Yields in the United States in the Twentieth Century. Weed Technology 12:752-760.

3. Beketov MA, Kefford BJ, Schafer RB, Liess M. 2013. Pesticides reduce regional biodiversity of stream invertebrates. Proc Natl Acad Sci U S A 110:11039-43.

4. Geiger F, Bengtsson J, Berendse F, Weisser WW, Emmerson M, Morales MB, Ceryngier P, Liira J, Tscharntke T, Winqvist C, Eggers S. 2010. Persistent negative effects of pesticides on biodiversity and biological control potential on European farmland. Basic and Applied Ecology 11:97-102.

5. Sánchez-Bayo F, Wyckhuys KA. 2019. Worldwide decline of the entomofauna: A review of its drivers. Biological Conservation 232:8-27.

6. Fukuto TR. 1990. Mechanism of action of organophosphorus and carbamate insecticides. Environ Health Perspect 87:245-54.

7. Eddleston M, Buckley NA, Eyer P, Dawson AH. 2008. Management of acute organophosphorus pesticide poisoning, p 597-607, Lancet, vol 371.

8. Terry AV, Jr. 2012. Functional consequences of repeated organophosphate exposure: potential non-cholinergic mechanisms. Pharmacol Ther 134:355-65.

9. Hancock DB, Martin ER, Mayhew GM, Stajich JM, Jewett R, Stacy MA, Scott BL, Vance JM, Scott WK. 2008. Pesticide exposure and risk of Parkinson's disease: a family-based case-control study. BMC Neurol 8:6. 
10. Chakraborty S, Mukherjee S, Roychoudhury S, Siddique S, Lahiri T, Ray MR. 2009. Chronic exposures to cholinesterase-inhibiting pesticides adversely affect respiratory health of agricultural workers in India. J Occup Health 51:488-97.

11. Hayden KM, Norton MC, Darcey D, Ostbye T, Zandi PP, Breitner JC, Welsh-Bohmer KA. 2010. Occupational exposure to pesticides increases the risk of incident AD: the Cache County study. Neurology 74:1524-30.

12. Slotkin TA. 2011. Does early-life exposure to organophosphate insecticides lead to prediabetes and obesity? Reprod Toxicol 31:297-301.

13. Rauh VA, Garfinkel R, Perera FP, Andrews HF, Hoepner L, Barr DB, Whitehead R, Tang D, Whyatt RW. 2006. Impact of prenatal chlorpyrifos exposure on neurodevelopment in the first 3 years of life among inner-city children. Pediatrics 118:e1845-59.

14. Clune AL, Ryan PB, Barr DB. 2012. Have Regulatory Efforts to Reduce Organophosphorus Insecticide Exposures Been Effective?, p 521-5, Environ Health Perspect, vol 120.

15. Roberts JR, Reigart JR. 2013. Recognition and management of pesticide poisonings. Agency EP,

16. Solomon KR, Williams WM, Mackay D, Purdy J, Giddings JM, Giesy JP. 2014. Properties and uses of chlorpyrifos in the United States. Rev Environ Contam Toxicol 231:13-34.

17. Egelko B. 2019-05-09 2019. California to block food pesticide that Trump's EPA saved from nationwide ban, $\mathrm{p}$ In San Francisco Chronicle. https://www.sfchronicle.com/science/article/California-moves-to-ban-pesticide-widely-usedby-13829656.php.

18. Barron M, Woodburn K. 1995. Ecotoxicology of Chlorpyrifos. Reviews of environmental contamination and toxicology 144.

19. Halstead NT, Civitello DJ, Rohr JR. 2015. Comparative Toxicities of Organophosphate and Pyrethroid Insecticides to Aquatic Macroarthropods. Chemosphere 135.

20. Giddings JM, Williams WM, Solomon KR, Giesy JP. 2014. Risks to Aquatic Organisms From Use of Chlorpyrifos in the United States. Reviews of environmental contamination and toxicology 231.

21. Di Nica V, González ABM, Lencioni V, Villa S. 2019. Behavioural and Biochemical Alterations by Chlorpyrifos in Aquatic Insects: An Emerging Environmental Concern for Pristine Alpine Habitats. Environmental science and pollution research international.

22. van Wijngaarden R, Leeuwangh P, Lucassen WG, Romijn K, Ronday R, van der Velde R, Willigenburg W. 1993. Acute Toxicity of Chlorpyrifos to Fish, a Newt, and Aquatic Invertebrates. Bulletin of environmental contamination and toxicology 51.

23. Urlacher E, Monchanin C, Rivière C, Richard FJ, Lombardi C, Michelsen-Heath S, Hageman KJ, Mercer AR. 2016. Measurements of Chlorpyrifos Levels in Forager Bees and Comparison With Levels That Disrupt Honey Bee Odor-Mediated Learning Under Laboratory Conditions. Journal of chemical ecology 42.

24. Dai P, Jack C, Mortensen A, Bustamante T, Bloomquist J, Ellis J. 2019. Chronic Toxicity of Clothianidin, Imidacloprid, Chlorpyrifos, and Dimethoate to Apis Mellifera L. Larvae Reared in Vitro. Pest management science 75.

25. Cutler G, Purdy J, Giesy J, Solomon K. 2014. Risk to Pollinators From the Use of Chlorpyrifos in the United States. Reviews of environmental contamination and toxicology 231.

26. Yang Y, Ma S, Yan Z, Liu F, Diao Q, Dai P. 2019. Effects of Three Common Pesticides on Survival, Food Consumption and Midgut Bacterial Communities of Adult Workers Apis Cerana and Apis Mellifera. Environmental pollution (Barking, Essex : 1987) 249.

27. Eng ML, Stutchbury BJM, Morrissey CA. 2017. Imidacloprid and Chlorpyrifos Insecticides Impair Migratory Ability in a Seed-Eating Songbird. Scientific reports 7. 
28. El-Nahhal Y, Lubbad R. 2018. Acute and Single Repeated Dose Effects of Low Concentrations of Chlorpyrifos, Diuron, and Their Combination on Chicken. Environmental science and pollution research international 25.

29. Narváez C, Ríos JM, Píriz G, Sanchez-Hernandez JC, Sabat P. 2016. Subchronic exposure to chlorpyrifos affects energy expenditure and detoxification capacity in juvenile Japanese quails. Chemosphere 144:775-784.

30. Singh PP, Kumar A, Chauhan RS, Pankaj PK. 2016. How Safe Is the Use of Chlorpyrifos: Revelations Through Its Effect on Layer Birds. Veterinary world 9.

31. Hernández AF, Parrón T, Tsatsakis AM, Requena M, Alarcón R, López-Guarnido O. 2013. Toxic Effects of Pesticide Mixtures at a Molecular Level: Their Relevance to Human Health. Toxicology 307.

32. Darwiche W, Gay-Quéheillard J, Delanaud S, El Khayat ESH, Khachfe H, Joumaa W, Bach V, Ramadan W. 2018. Impact of Chronic Exposure to the Pesticide Chlorpyrifos on Respiratory Parameters and Sleep Apnea in Juvenile and Adult Rats. PloS one 13.

33. Ezzi L, Belhadj SI, Haouas Z, Sakly A, Grissa I, Chakroun S, Kerkeni E, Hassine M, Mehdi M, Ben CH. 2016. Histopathological and Genotoxic Effects of Chlorpyrifos in Rats. Environmental science and pollution research international 23.

34. Aroonvilairat S, Tangjarukij C, Sornprachum T, Chaisuriya P, Siwadune T, Ratanabanangkoon K. 2018. Effects of Topical Exposure to a Mixture of Chlorpyrifos, Cypermethrin and Captan on the Hematological and Immunological Systems in Male Wistar Rats. Environmental toxicology and pharmacology 59.

35. Uzun FG, Demir F, Kalender S, Bas H, Kalender Y. 2010. Protective Effect of Catechin and Quercetin on Chlorpyrifos-Induced Lung Toxicity in Male Rats. Food and chemical toxicology : an international journal published for the British Industrial Biological Research Association 48.

36. Owumi SE, Dim UJ. 2019. Manganese Suppresses Oxidative Stress, Inflammation and caspase-3 Activation in Rats Exposed to Chlorpyrifos. Toxicology reports 6.

37. Morgan MK, Sheldon LS, Croghan CW, Jones PA, Robertson GL, Chuang JC, Wilson NK, Lyu CW. 2005. Exposures of Preschool Children to Chlorpyrifos and Its Degradation Product 3,5,6trichloro-2-pyridinol in Their Everyday Environments. Journal of exposure analysis and environmental epidemiology 15.

38. Rauh V, Arunajadai S, Horton M, Perera F, Hoepner L, Barr DB, Whyatt R. 2011. Seven-year Neurodevelopmental Scores and Prenatal Exposure to Chlorpyrifos, a Common Agricultural Pesticide. Environmental health perspectives 119.

39. Morrissey JP, Dow JM, Mark GL, O'Gara F. 2004. Are microbes at the root of a solution to world food production?, p 922-6, EMBO Rep, vol 5.

40. Gage DJ. 2004. Infection and invasion of roots by symbiotic, nitrogen-fixing rhizobia during nodulation of temperate legumes. Microbiol Mol Biol Rev 68:280-300.

41. Azarias Guimaraes A, Duque Jaramillo PM, Simao Abrahao Nobrega R, Florentino LA, Barroso Silva K, de Souza Moreira FM. 2012. Genetic and symbiotic diversity of nitrogen-fixing bacteria isolated from agricultural soils in the western Amazon by using cowpea as the trap plant. Appl Environ Microbiol 78:6726-33.

42. Gougoulias C, Clark JM, Shaw LJ. 2014. The Role of Soil Microbes in the Global Carbon Cycle: Tracking the Below-Ground Microbial Processing of Plant-Derived Carbon for Manipulating Carbon Dynamics in Agricultural Systems. Journal of the science of food and agriculture 94:236271.

43. Bloemberg GV, Lugtenberg BJ. 2001. Molecular basis of plant growth promotion and biocontrol by rhizobacteria. Curr Opin Plant Biol 4:343-50. 
44. Dimkpa C, Weinand T, Asch F. 2009. Plant-rhizobacteria interactions alleviate abiotic stress conditions. Plant Cell Environ 32:1682-94.

45. Mendes R, Garbeva P, Raaijmakers JM. 2013. The rhizosphere microbiome: significance of plant beneficial, plant pathogenic, and human pathogenic microorganisms. FEMS Microbiol Rev 37:634-63.

46. White JF, Kingsley KL, Zhang Q, Verma R, Obi N, Dvinskikh S, Elmore MT, Verma SK, Gond SK, Kowalski KP. 2019. Review: Endophytic Microbes and Their Potential Applications in Crop Management. Pest management science 75:2558-2565.

47. Supreeth M, Chandrashekar MA, Sachin N, Raju NS. 2016. Effect of Chlorpyrifos on Soil Microbial Diversity and Its Biotransformation by Streptomyces Sp. HP-11. 3 Biotech 6.

48. Yadav M, Shukla AK, Srivastva N, Upadhyay SN, Dubey SK. 2016. Utilization of Microbial Community Potential for Removal of Chlorpyrifos: A Review. Critical reviews in biotechnology 36.

49. Yang C, Liu N, Guo X, Qiao C. 2006. Cloning of mpd gene from a chlorpyrifos-degrading bacterium and use of this strain in bioremediation of contaminated soil. FEMS Microbiol Lett 265:118-25.

50. Anwar S, Liaquat F, Khan QM, Khalid ZM, Iqbal S. 2009. Biodegradation of chlorpyrifos and its hydrolysis product 3,5,6-trichloro-2-pyridinol by Bacillus pumilus strain C2A1. J Hazard Mater 168:400-5.

51. Chishti Z, Hussain S, Arshad K, Khalid A, Arshad M. 2013. Microbial Degradation of Chlorpyrifos in Liquid Media and Soil. Journal of environmental management 114.

52. Shabbir M, Singh M, Maiti S, Kumar S, Saha SK. 2018. Removal Enactment of OrganoPhosphorous Pesticide Using Bacteria Isolated From Domestic Sewage. Bioresource technology 263.

53. Aswathi A, Pandey A, Sukumaran RK. 2019. Rapid degradation of the organophosphate pesticide-Chlorpyrifos by a novel strain of Pseudomonas nitroreducens AR-3. Bioresource technology 292:122025.

54. Jaiswal DK, Verma JP, Krishna R, Gaurav AK, Yadav J. 2019. Molecular Characterization of Monocrotophos and Chlorpyrifos Tolerant Bacterial Strain for Enhancing Seed Germination of Vegetable Crops. Chemosphere 223.

55. Gong T, Xu X, Dang Y, Kong A, Wu Y, Liang P, Wang S, Yu H, Xu P, Yang C. 2018. An Engineered Pseudomonas Putida Can Simultaneously Degrade Organophosphates, Pyrethroids and Carbamates. The Science of the total environment 628-629.

56. Fang H, Yu YL, Wang XG, Chu XQ, Pan XD, Yang XE. 2008. Effects of Repeated Applications of Chlorpyrifos on Its Persistence and Soil Microbial Functional Diversity and Development of Its Degradation Capability. Bulletin of environmental contamination and toxicology 81.

57. Abraham J, Shanker A, Silambarasan S. 2013. Role of Gordonia Sp JAAS1 in Biodegradation of Chlorpyrifos and Its Hydrolysing Metabolite 3,5,6-trichloro-2-pyridinol. Letters in applied microbiology 57.

58. Siddavattam D, Yakkala H, Samantarrai D. 2019. Lateral Transfer of Organophosphate Degradation ( opd) Genes Among Soil Bacteria: Mode of Transfer and Contributions to Organismal Fitness. Journal of genetics 98.

59. Seo JS, Keum YS, Harada RM, Li QX. 2007. Isolation and Characterization of Bacteria Capable of Degrading Polycyclic Aromatic Hydrocarbons (PAHs) and Organophosphorus Pesticides From PAH-contaminated Soil in Hilo, Hawaii. Journal of agricultural and food chemistry 55.

60. Horne I, Sutherland TD, Harcourt RL, Russell RJ, Oakeshott JG. 2002. Identification of an opd (Organophosphate Degradation) Gene in an Agrobacterium Isolate, p 3371-6, Appl Environ Microbiol, vol 68. 
601

602

603

604

605

606

607

608

609

610

61. Dumas DP, Caldwell SR, Wild JR, Raushel FM. 1989. Purification and Properties of the Phosphotriesterase From Pseudomonas Diminuta. The Journal of biological chemistry 264.

62. Cheng T, Harvey S, Stroup A. 1993. Purification and Properties of a Highly Active Organophosphorus Acid Anhydrolase From Alteromonas Undina. Applied and environmental microbiology 59.

63. Abhishek W, Kamaljeet S, Sudesh K. 2018. Effect of Chlorpyrifos and Malathion on Soil Microbial Population and Enzyme Activity. Acta Scientific Microbiology 1:14-22.

64. Roman P, Cardona D, Sempere L, Carvajal F. 2019. Microbiota and organophosphates. Neurotoxicology 75:200-208.

65. Bhatti A, Haq S, Bhat R. 2017. Actinomycetes Benefaction Role in Soil and Plant Health. Microbial pathogenesis 111 .

66. Barka EA, Vatsa P, Sanchez L, Gaveau-Vaillant N, Jacquard C, Klenk HP, Clément C, Ouhdouch Y, van Wezel GP. 2016. Taxonomy, Physiology, and Natural Products of Actinobacteria, p 1-43, Microbiol Mol Biol Rev, vol 80.

67. Minas W, Bailey JE, Duetz W. 2000. Streptomycetes in Micro-Cultures: Growth, Production of Secondary Metabolites, and Storage and Retrieval in the 96-well Format. Antonie van Leeuwenhoek 78.

68. Yoon V, Nodwell JR. 2014. Activating Secondary Metabolism With Stress and Chemicals. Journal of industrial microbiology \& biotechnology 41.

69. Seyedsayamdost MR. 2014. High-throughput Platform for the Discovery of Elicitors of Silent Bacterial Gene Clusters. Proceedings of the National Academy of Sciences of the United States of America 111.

70. Traxler MF, Watrous JD, Alexandrov T, Dorrestein P, Kolter R. 2013. Interspecies Interactions Stimulate Diversification of the Streptomyces Coelicolor Secreted Metabolome. mBio 4.

71. Caceres T, He W, Naidu R, Megharaj M. 2007. Toxicity of chlorpyrifos and TCP alone and in combination to Daphnia carinata: the influence of microbial degradation in natural water. Water Res 41:4497-503.

72. Li J, Liu J, Shen W, Zhao X, Hou Y, Cao H, Cui Z. 2010. Isolation and characterization of 3,5,6trichloro-2-pyridinol-degrading Ralstonia sp. strain T6. Bioresour Technol 101:7479-83.

73. Eaton DL, Daroff RB, Autrup H, Bridges J, Buffler P, Costa LG, Coyle J, McKhann G, Mobley WC, Nadel L, Neubert D, Schulte-Hermann R, Spencer PS. 2008. Review of the Toxicology of Chlorpyrifos With an Emphasis on Human Exposure and Neurodevelopment. Critical reviews in toxicology 38 Suppl 2.

74. Tomlin CD. 2009. The pesticide manual: A world compendium. British Crop Production Council.

75. Mackay D, Glesy JP, Solomon KR. 2014. Fate in the Environment and Long-Range Atmospheric Transport of the Organophosphorus Insecticide, Chlorpyrifos and Its Oxon, p 35-76. In Giesy J, Solomon K (ed), Ecological Risk Assessment for Chlorpyrifos in Terrestrial and Aquatic Systems in the United States. Springer International Publishing, Reviews of Environmental Contamination and Toxicology.

76. Ensign JC. 1978. Formation, Properties, and Germination of Actinomycete Spores. Annual review of microbiology 32.

77. Claessen D, Stokroos I, Deelstra H, Penninga N, Bormann C, Salas J, Dijkhuizen L, Wösten H. 2004. The Formation of the Rodlet Layer of Streptomycetes Is the Result of the Interplay Between Rodlins and Chaplins. Molecular microbiology 53.

78. Claessen D, de Jong W, Dijkhuizen L, Wösten H. 2006. Regulation of Streptomyces Development: Reach for the Sky! Trends in microbiology 14.

79. Ekkers DM, Claessen D, Galli F, Stamhuis E. 2014. Surface Modification Using Interfacial Assembly of the Streptomyces Chaplin Proteins. Applied microbiology and biotechnology 98. 
80. Andam C, Doroghazi J, Campbell A, Kelly P, Choudoir M, Buckley D. 2016. A Latitudinal Diversity Gradient in Terrestrial Bacteria of the Genus Streptomyces. mBio 7.

81. Chenu C, Cosentino D. 2011. Microbial regulation of soil structural dynamics. The architecture and biology of soils: life in inner space:37-70.

82. Miller RM, Jastrow JD. 2000. Mycorrhizal fungi influence soil structure, p 3-18, Arbuscular mycorrhizas: physiology and function. Springer.

83. Lin VS, Volk RF, DeLeon AJ, Anderson LN, Purvine SO, Shukla AK, Bernstein HC, Smith JN, Wright AT. 2020. Structure Dependent Determination of Organophosphate Targets in Mammalian Tissues Using Activity-Based Protein Profiling. Chemical research in toxicology 33.

84. Carmany D, Walz AJ, Hsu FL, Benton B, Burnett D, Gibbons J, Noort D, Glaros T, Sekowski JW. 2017. Activity Based Protein Profiling Leads to Identification of Novel Protein Targets for Nerve Agent VX. Chemical research in toxicology 30.

85. Nomura DK, Casida JE. 2011. Activity-based protein profiling of organophosphorus and thiocarbamate pesticides reveals multiple serine hydrolase targets in mouse brain. Journal of agricultural and food chemistry 59:2808-2815.

86. Dar MA, Kaushik G, Villarreal-Chiu JF. 2019. Pollution Status and Bioremediation of Chlorpyrifos in Environmental Matrices by the Application of Bacterial Communities: A Review. Journal of environmental management 239.

87. Mishra T, Govindharaj GP, Gadratagi BG, Patil NB, Yadav MK, Munda S, Mukherjee AK, Jena M, Adak T. 2019. Deciphering the associated risk on soil microbes upon use of biopesticides in rice ecosystem. Environ Monit Assess 191:654.

88. Wang F, Yao J, Chen H, Chen K, Trebse P, Zaray G. 2010. Comparative toxicity of chlorpyrifos and its oxon derivatives to soil microbial activity by combined methods. Chemosphere 78:319-26.

89. Mehjin A M A-A, Hmoshi RM, Kanaan IA, Thanoon AA. 2019. Effect of pesticides on soil microorganisms. Journal of Physics: Conference Series 1294.

90. Suvarchala G, Philip GH. 2016. Toxicity of 3,5,6-trichloro-2-pyridinol Tested at Multiple Stages of Zebrafish (Danio Rerio) Development. Environmental science and pollution research international 23.

91. Kashanian S, Shariati Z, Roshanfekr H, Ghobadi S. 2012. DNA Binding Studies of 3, 5, 6-trichloro2-pyridinol Pesticide Metabolite. DNA and cell biology 31.

92. Casida J, Quistad G. 2005. Serine Hydrolase Targets of Organophosphorus Toxicants. Chemicobiological interactions 157-158.

93. Yang LL, Yang X, Li GB, Fan KG, Yin PF, Chen XG. 2016. An Integrated Molecular Docking and Rescoring Method for Predicting the Sensitivity Spectrum of Various Serine Hydrolases to Organophosphorus Pesticides. Journal of the science of food and agriculture 96.

94. Weber CF, Werth JT. 2015. Culturing Life From Air: Using a Surface Air System to Introduce Discovery-Based Research in Aerobiology Into the Undergraduate Biology Curriculum. Journal of microbiology \& biology education 16.

95. Kieser T, Bibb MJ, Buttner MJ, Chater KF, Hopwood DA. 2000. Practical streptomyces genetics, vol 291. John Innes Foundation Norwich. 


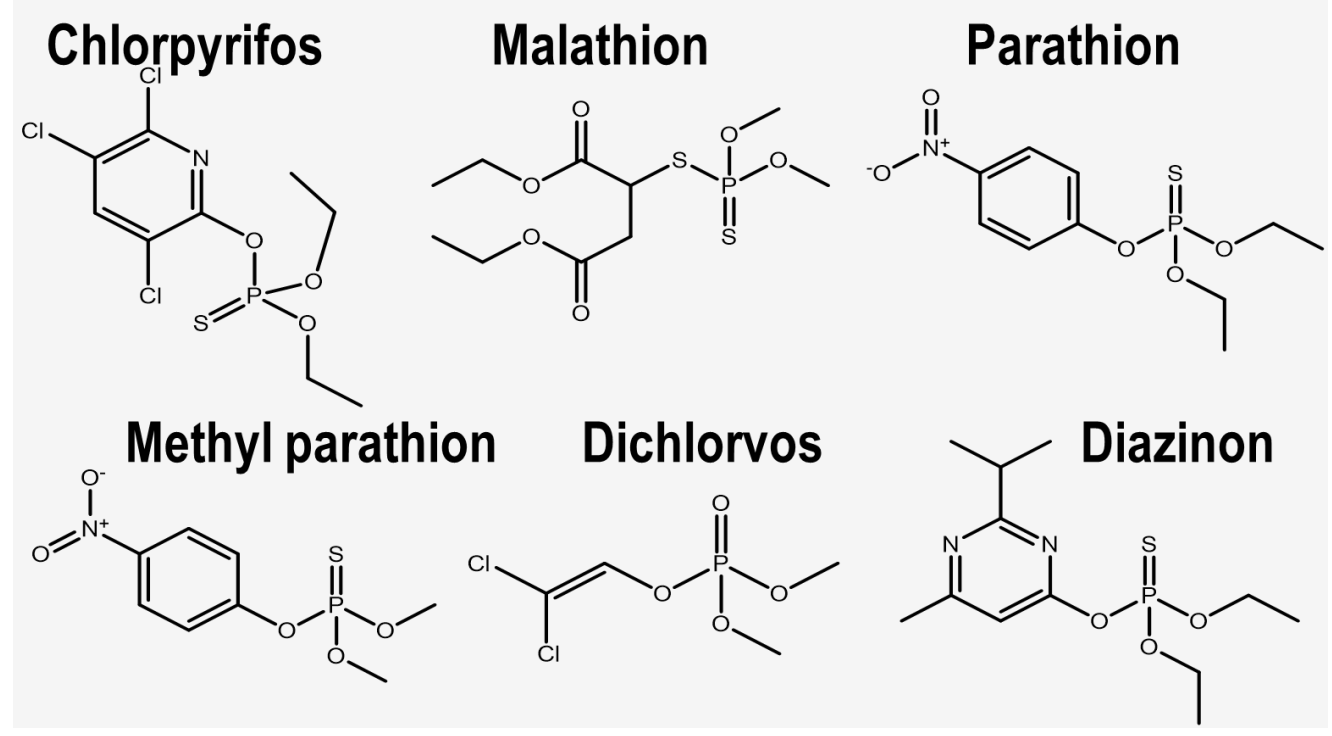

Figure 1: Representative organophosphate pesticides 


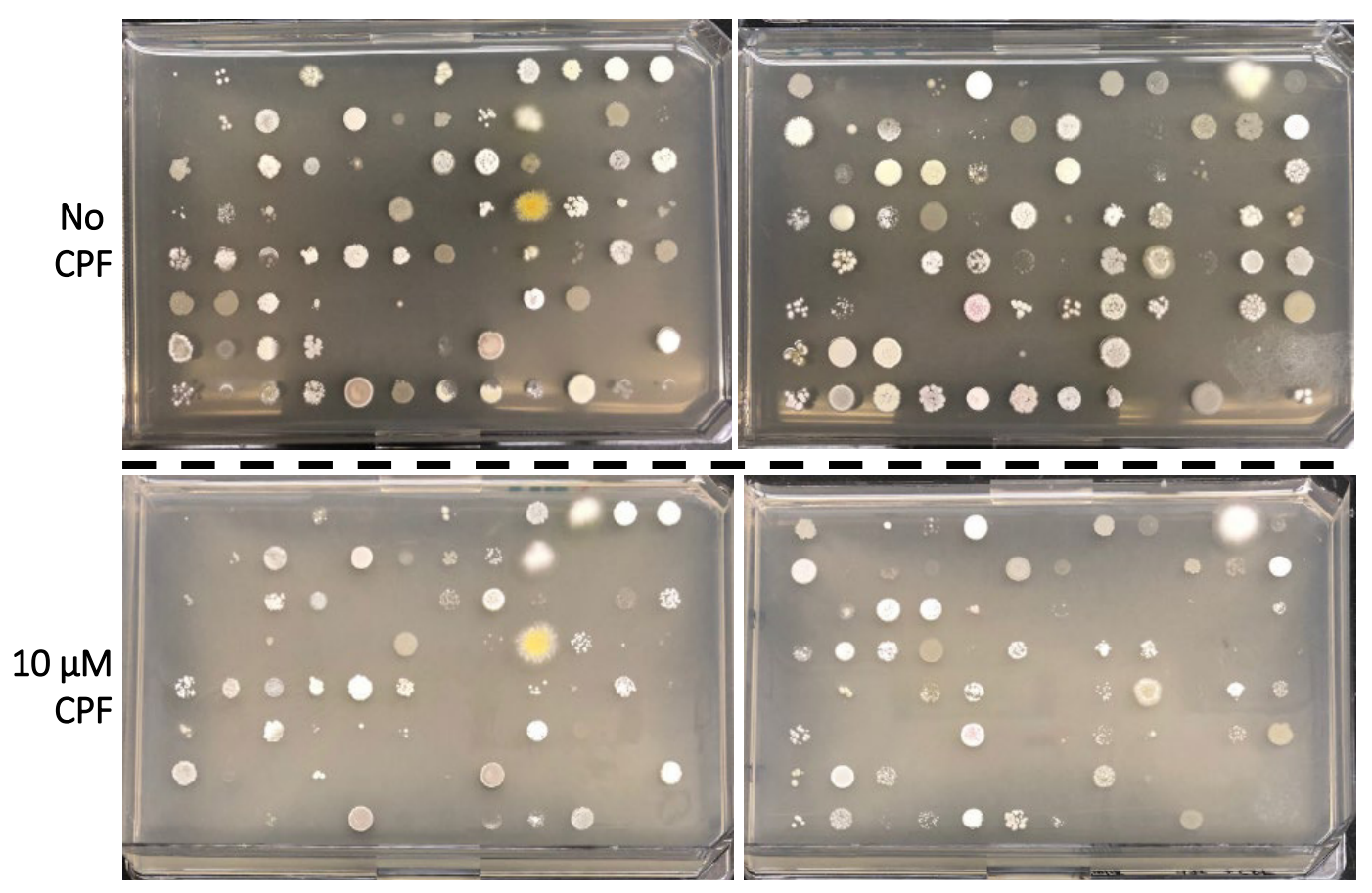

Figure 2: Screening the effects of chlorpyrifos exposure against a library of actinomycetes. A library of 196 actinomycetes were replica plated on media containing DMSO (Top) or $10 \mu \mathrm{M}$ CPF (Bottom). Of the 196 strains plated 144 representative grew robustly on the DMSO control plates which served as the reference. The strains grown on CPF were compared to the counterpart on DMSO media. 

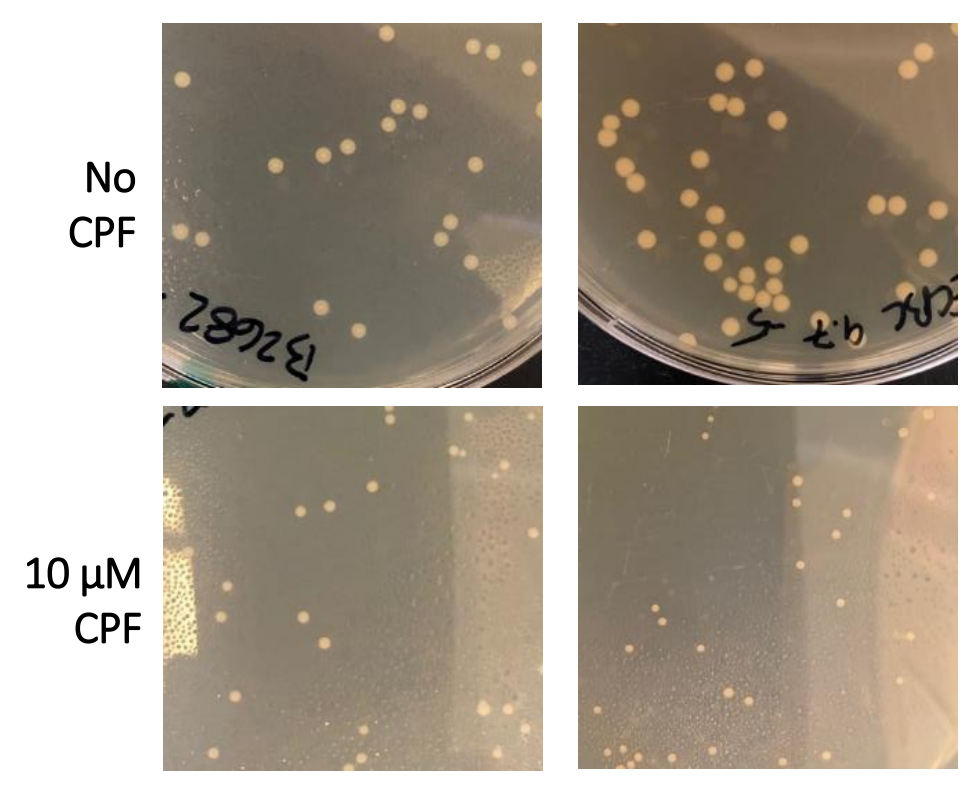

\section{Effect of Chlorpyrifos on Colony Growth 3 days, ISP2}

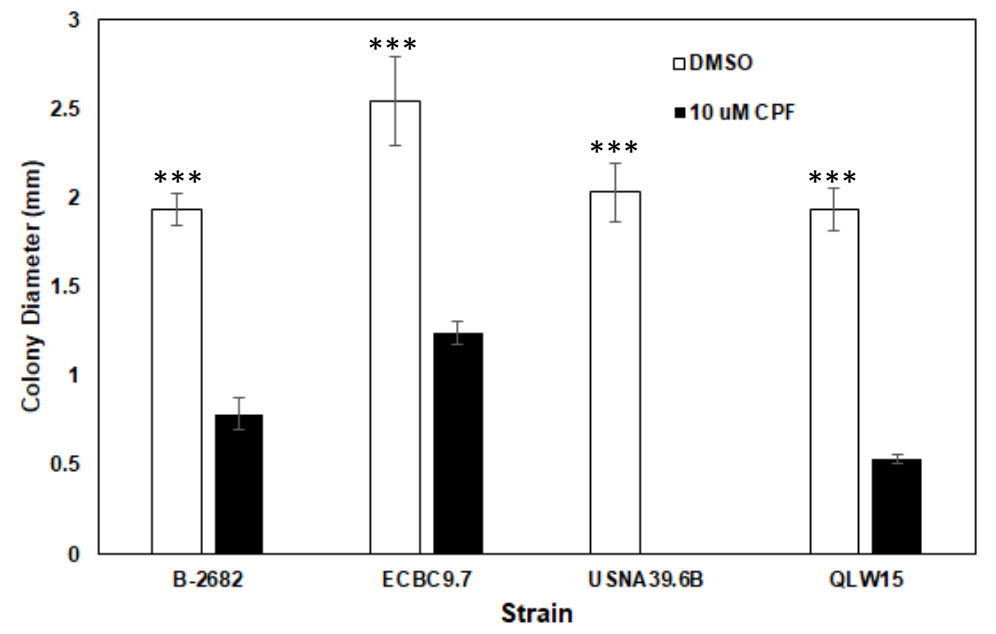

Figure 3: Effect of chlorpyrifos on colony size. Four Streptomyces strains were each inoculated onto an ISP2 agar plate with $10 \mu \mathrm{M} \mathrm{CPF}$ or DMSO and incubated for 3 days at $26^{\circ} \mathrm{C}$. The diameter of a sampling of colonies was measured, represented (Top). The mean diameters for each strain tested were determined (bottom). Error bars represent SD. ${ }^{* * *} p<0.001$ based on unpaired t-test between mean diameters from $+/$ - CPF treatments. 

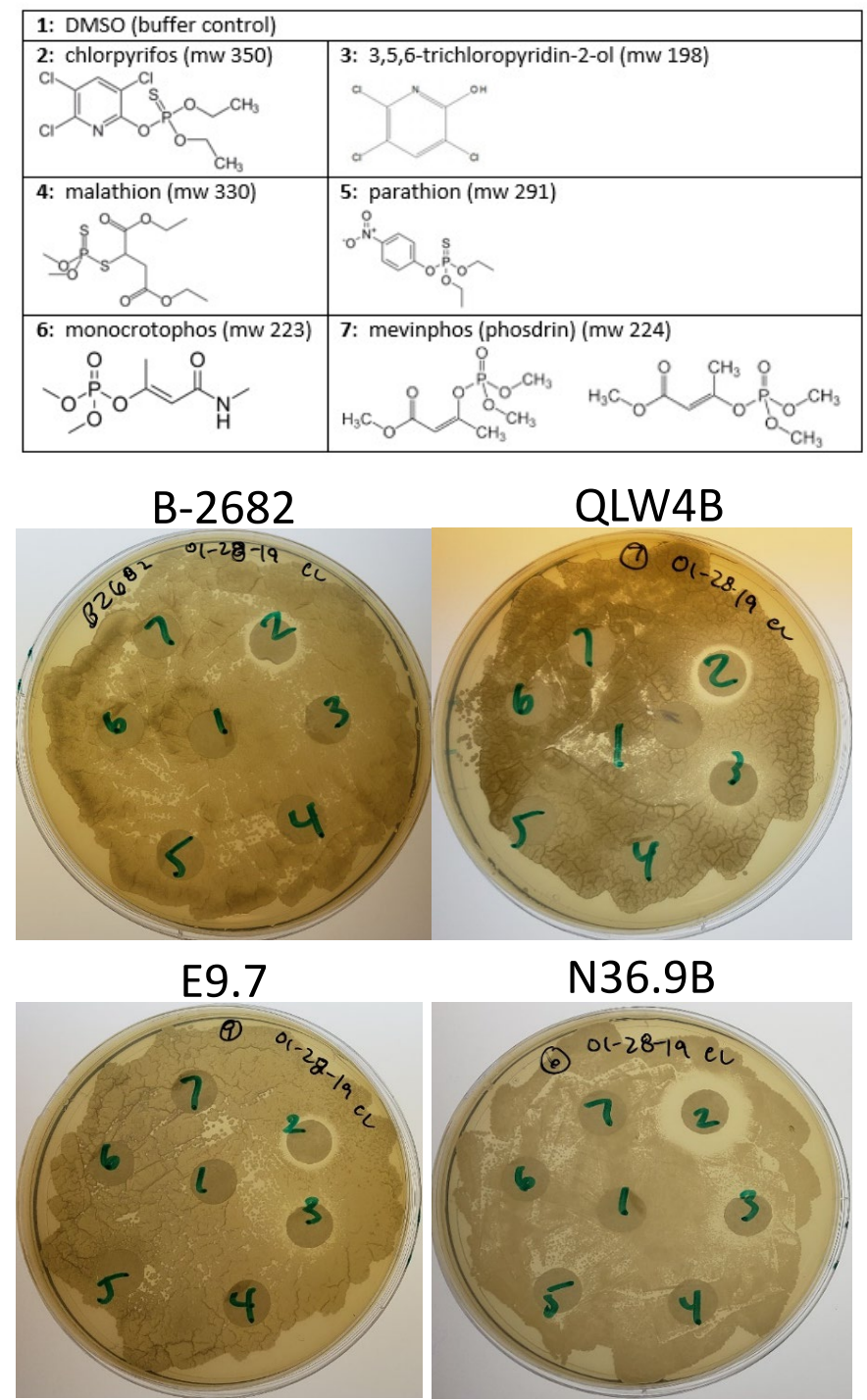

Mycobacterium smegmatis

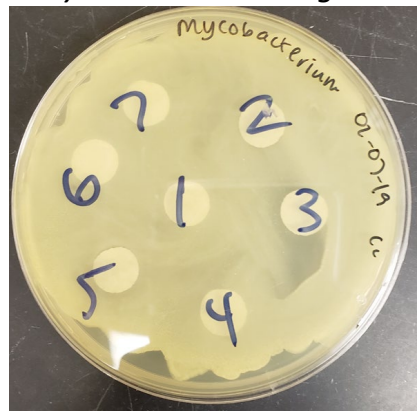

Figure 4: Determining the inhibitory effects of organophosphate pesticides

on

actinomycetes. Four Streptomyces strains and Mycobacterium smegmatis were each inoculated onto an ISP2 agar plate with discs dosed with $10 \mathrm{uL}$ of 10 $\mu \mathrm{M}$ of (1) DMSO; (2) CPF; (3) TCP; (4) Malathion; (5) Parathion; (6) Monocrotophos; (7) Mevinphos and incubated allowing lawns to form. Following incubation zones of inhibition (ZOIs) were measured for each of the compounds tested. 


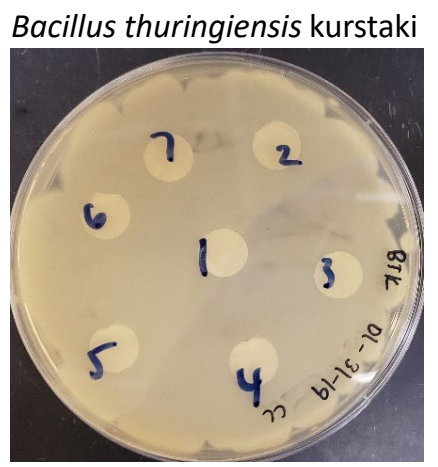

\section{Burkholderia thailandensis}

Escherichia coli
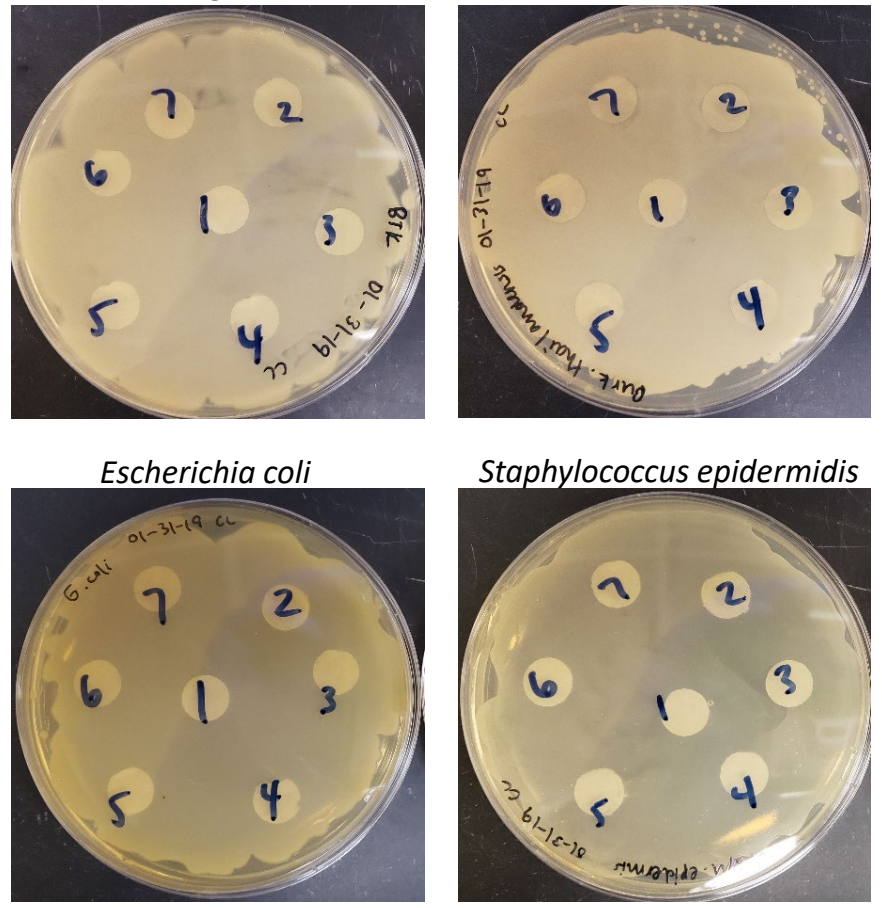

Staphylococcus epidermidis

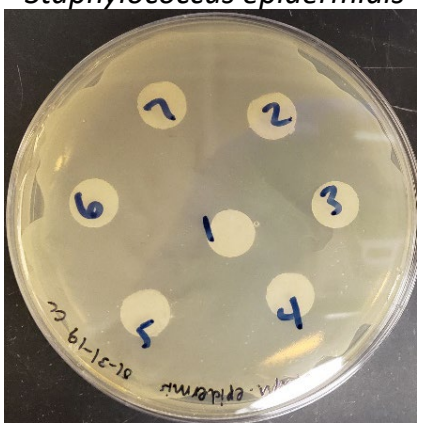

Figure 5: Determining the inhibitory effects of organophosphate pesticides on nonactinomycetes. Four representative bacteria: Bacillus thuringiensis kurstaki, Burkholderia thailandensis, Escherichia coli, and Staphylococcus epidermidis, and were each inoculated on appropriate media with discs dosed with 10uL of 10 $\mu \mathrm{M}$ of (1) DMSO; (2) CPF; (3) TCP; (4) Malathion; (5) Parathion; (6) Monocrotophos; (7) Mevinphos and incubated allowing lawns to form. Following incubation zones of inhibition (ZOIs) were measured for each of the compounds tested. 